\title{
Hypoglycaemic Activity of Bitter Gourd Fruits Extracts in Normal and Alloxan-Induced Diabetic Rats
}

Othman Ali Othman*

Department of Biochemistry, Faculty of Science, Minia University, El-Minia, Egypt

\begin{abstract}
The purpose of the study was to investigate the effect of bitter gourd fruits (Momordica charantia) extracts on blood glucose concentration and liver enzymes in normal and alloxan-induced diabetic rats.

Oral administration of an aqueous extract of bitter gourd fruits (BGF) to alloxan diabetic rats caused a significant reduction of blood glucose and serum transaminases (aminotransferases). However, bitter gourd fruits extract didn't affect the blood glucose in normal rats.

Maximum reduction in serum glucose was observed after $4 \mathrm{~h}$ at a dose level of $50 \mathrm{mg}$ extract $/ \mathrm{kg}$ of body weight and considers the optimum dose. Chronic administration of the extract significantly reduced the blood glucose in alloxan-induced diabetic rats for fifteen days. The bitter gourd fruits extract also lowers the aspartate transaminase (sAST) and alanine transaminase (sALT) in diabetic rats.

Thus results suggest that the bitter gourd fruits not only reduce blood glucose level, but may be able to ameliorate biochemical damages reduced by alloxan in diabetic rats.
\end{abstract}

Keywords: Bitter gourd; Hypoglycaemic activity; Transaminases

\section{Introduction}

Diabetes mellitus is a major disease that affects more than one hundred million people and may attain about five times more subjects in the next ten years [1]. Its control involves exercise, diet and chemotherapy. However, the pharmaceutical drugs at the authors disposal are either too expensive or have undesirable side effects and contraindications [2-4]. Historically, the study of the pathogenesis of diabetes mellitus was in the traditional pattern of endocrinology, the major dysfunction of $ß$-cells associated with the pre-overt phase of type I diabetes or with type II diabetes is a decreased secretory response to glucose [5-7].

After insulin became available, evidence emerged suggesting that human diabetes mellitus has a multifactorial etiology. Insulin was and still the major hypoglycaemic medication used in diabetes mellitus treatment. In order to discover other hypoglycaemic agents, many investigations have been performed in traditional medicine testing eventual hypoglycaemic plants [8-12]. In this view, many studies have demonstrated hypoglycaemic activity of some plants in different animal models [13-16].

The bitter gourd was widely distributed in New Valley Governorate (Egypt). Its water extract was largely used in Egypt on traditional medicine as anti-diabetic without scientific background.

In this study it has been investigated the effect of extract of bitter gourd on blood glucose and serum transaminases in normal and alloxan induced diabetic rats.

\section{Materials and Methods}

\section{Plant materials}

Bitter gourd fruits were collected from New Valley Governorate in JulySeptember 2002, and dried. Plant material was prepared according to the traditional method $10 \mathrm{~g}$ of dried sample was boiled at $100^{\circ} \dot{\mathrm{C}}$ in $100 \mathrm{ml}$ of distilled water for $10 \mathrm{~min}$. Then cooled at room temperature for $20 \mathrm{~min}$ and filtered. The water extract was prepared daily just before administration.

\section{Animals}

Male albino rats (Rattus norvegicus) were examined well to ensure that they are free from any signs of microbial or parasitic diseases. Their body weights were about $(120 \pm 10 \mathrm{~g})$. Rats were adapted in large cages with sawdust bottom coating to the controlled laboratory conditions for three weeks before carrying out the inoculation procedures and they were provided with commercial rodent food pellets and water.

Effect of bitter gourd fruits extract on blood glucose and liver enzymes levels of normal rats

Normal rats were divided into four groups of eight rats per groups.

Group I: (Untreated controls) Group rats receive distilled water and served as control group.

Group II: (Treated controls) Normal rats receiving ( $25 \mathrm{mg} / \mathrm{kg}$ body weight) orally the BGF extract.

Group III: (Treated controls) Normal rats receiving $(50 \mathrm{mg} / \mathrm{kg}$ body weight) orally the BGF extract.

Group IV: Normal rats receiving (100 mg/kg body weight) orally the BGF extract.

Blood samples for plasma glucose and liver enzymes determination was obtained by a tail vein at 2, 4 and 6 hours after giving drug extract [17-19].

\section{Alloxan-induced hyperglycemia in rats}

Hyperglycemia was induced by the intraperitonaly injection of

*Corresponding author: Othman Ali Othman, Department of Biochemistry, Faculty of Science, Minia University, El-Minia, Egypt, Tel: +20 19623; E-mail: othman_egy@yahoo.com

Received June 23, 2016; Accepted July 29, 2016; Published August 09, 2016

Citation: Othman OA (2016) Hypoglycaemic Activity of Bitter Gourd Fruits Extracts in Normal and Alloxan-Induced Diabetic Rats. J Microb Biochem Technol 8: 358 360. doi: 10.4172/1948-5948.1000308

Copyright: (C 2016 Othman OA. This is an open-access article distributed under the terms of the Creative Commons Attribution License, which permits unrestricted use, distribution, and reproduction in any medium, provided the original author and source are credited. 
alloxan (120 mg/kg body weight) dissolved in distilled water. Five days after injection of alloxan blood glucose levels of all surviving rats were determined only animals with blood glucose levels over than $350 \mathrm{mg} /$ $\mathrm{dl}$ were used.

\section{Effect of the bitter gourd fruits extraction on alloxan induced diabetic rats}

The diabetic rats were divided into four groups each group contain eight rats group I (control group) were given distilled water orally, while group II, group III and group IV were given water extract 25,50 and $100 \mathrm{mg} / \mathrm{kg}$ body weight. Blood sample were collected from the tail vein 2, 4 and $6 \mathrm{~h}$ after the water extract administration.

\section{Hypoglycaemic effect of water extract on alloxan-induced diabetic rats through longer duration}

Male albino rats were divided five groups of eight rats in each group. Group I (normal rats) were given distilled water and served as normal. Group II (control diabetic) diabetic rats were given distilled water instead of extract. Groups III-V was given BGF extract orally at dose 25, 50 and 100 body weights. The oral administration of BGF extract was continued for fifteen days. Blood samples were collected from tail vein after 5, 10 and 15 days.

\section{Biochemical analysis}

Blood sugar was determined according to the method described by Trinder, ALT and AST by Reitman and Frankel [20-23].

\section{Statistical analysis}

Results are represented as mean \pm standard deviation (S.D). A two way analysis variance (ANOVA) according to Mason [19] for testing the significance between alloxan controls, treated and control group was performed.

\section{Results}

Change in blood glucose level in normal and treated rats with different dose of BGF were presented in Table 1. Administration of BGF extract was found didn't reduce blood glucose level in normal rats.

Table 2 show the effect of various doses of the extract of BGF on blood glucose level in diabetic rats. The blood glucose was increased

\begin{tabular}{|c|c|c|c|c|c|}
\hline \multirow{2}{*}{ Groups } & \multirow{2}{*}{ Treatment } & \multicolumn{4}{|c|}{ Mean Blood Glucose (mg/dl) } \\
\cline { 3 - 6 } & & Initial & $\mathbf{2}$ h & $\mathbf{4 h}$ & $\mathbf{6 ~ h}$ \\
\hline I & Control & $74 \pm 3$ & $77 \pm 2$ & $75 \pm 2$ & $76 \pm 3$ \\
\hline II & BGF 25 X & $71 \pm 2$ & $69 \pm 2$ & $72 \pm 2$ & $71 \pm 2$ \\
\hline III & BGF 50 X & $73 \pm 3$ & $71 \pm 2$ & $67 \pm 2$ & $69 \pm 3$ \\
\hline IV & BGF 100 X & $72 \pm 2$ & $70 \pm 1$ & $69 \pm 3$ & $70 \pm 2$ \\
\hline
\end{tabular}

Table 1: Effect of bitter gourd fruits extract on blood glucose levels in normal rats.

\begin{tabular}{|c|c|c|c|c|c|}
\hline \multirow{2}{*}{ Groups } & \multirow{2}{*}{ Treatment } & \multicolumn{4}{|c|}{ Mean Blood Glucose (mg/dl) } \\
\cline { 3 - 6 } & Initial & $\mathbf{2 ~ h}$ & $\mathbf{4}$ h & $\mathbf{6} \mathbf{~ h}$ \\
\hline I & $\begin{array}{c}\text { Control } \\
\text { (distilled water) }\end{array}$ & $350 \pm 5$ & $352 \pm 6$ & $348 \pm 8$ & $346 \pm 7$ \\
\hline II & BGF 25 X & $355 \pm 9$ & $352 \pm 7$ & $349 \pm 8$ & $342 \pm 8$ \\
\hline III & BGF 50 X & $352 \pm 6$ & $315 \pm 7$ & $245^{\star} \pm 9$ & $260^{*} \pm 8$ \\
\hline IV & BGF 100 X & $360 \pm 9$ & $352 \pm 8$ & $301 \pm 7$ & $307 \pm 7$ \\
\hline
\end{tabular}

Result Mean \pm S.D

Significant $\mathrm{p}<0.05$

$\mathrm{X} \mathrm{mg/kg}$ body weight

Table 2: Effect of bitter gourd fruits extract on blood glucose levels in diabetic rats.

\begin{tabular}{|c|c|c|c|c|c|}
\hline \multirow{2}{*}{ Groups } & \multirow{2}{*}{ Treatment } & \multicolumn{4}{|c|}{ Mean Blood Glucose (mg/dI) } \\
\cline { 3 - 6 } & Initial & $\mathbf{5}$ days & $\mathbf{1 0}$ days & $\mathbf{1 5}$ days \\
\hline I & Normal & $78 \pm 2$ & $76 \pm 2$ & $80 \pm 2$ & $79 \pm 2$ \\
\hline II & $\begin{array}{c}\text { Diabetic } \\
\text { (Distilled water) }\end{array}$ & $360 \pm 8$ & $352 \pm 8$ & $311 \pm 9$ & $315 \pm 7$ \\
\hline III & BGF 25 X & $358 \pm 9$ & $249^{*} \pm 6$ & $188^{*} \pm 8$ & $178^{*} \pm 9$ \\
\hline IV & BGF 50X & $355 \pm 10$ & $225^{*} \pm 9$ & $165^{*} \pm 7$ & $155^{*} \pm 6$ \\
\hline V & BGF 100 X & $370 \pm 7$ & $235^{*} \pm 8$ & $175^{*} \pm 7$ & $168^{*} \pm 8$ \\
\hline
\end{tabular}

Table 3: Hypoglycaemic effect of BGF extract on blood glucose levels in diabetic rats through long duration.

\begin{tabular}{|c|c|c|c|c|c|}
\hline \multirow{2}{*}{ Groups } & \multirow{2}{*}{ Treatment } & \multicolumn{4}{|c|}{ Body weight (g) } \\
\cline { 3 - 6 } & & Initial & $\mathbf{5}$ days & 10 days & 15 days \\
\hline I & Normal & $118 \pm 2$ & $122 \pm 2$ & $132 \pm 1$ & $141 \pm 2$ \\
\hline II & Diabetic & $120 \pm 3$ & $102 \pm 2$ & $104 \pm 2$ & $106 \pm 3$ \\
\hline III & BGF 25 X & $116 \pm 3$ & $112 \pm 2$ & $114 \pm 3$ & $118 \pm 3$ \\
\hline IV & BGF 50 X & $117 \pm 4$ & $122 \pm 3$ & $126 \pm 3$ & $129 \pm 2$ \\
\hline V & BGF 100 X & $118 \pm 3$ & $120 \pm 2$ & $124 \pm 2$ & $128 \pm 2$ \\
\hline
\end{tabular}

Result Mean \pm S.D

Significant $p<0.05$

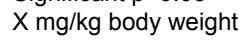

Table 4: Effect of BGF on body weight of normal and diabetic rats.

in alloxan diabetic rats as compared to normal rats. Administration of BGF extract decreased blood glucose as compared to diabetic rats. The maximum reduction was rated after $4 \mathrm{~h}$ after administration of the BGF extract. There was reduction of blood glucose in these rats four hours after the administration of BGF; $25 \mathrm{mg} / \mathrm{kg}$ body weight $(349 \pm 8 \mathrm{mg} / \mathrm{dl})$, $50 \mathrm{mg} / \mathrm{kg}$ body weight $(245 \pm 9 \mathrm{mg} / \mathrm{dl})$ and $100 \mathrm{mg} / \mathrm{kg}$ body weight (301 $\pm 7 \mathrm{mg} / \mathrm{dl})$ compared to diabetic rats $(355 \pm 9 \mathrm{mg} / \mathrm{dl}, 352 \pm 6 \mathrm{mg} / \mathrm{dl}$ and $360 \pm 9 \mathrm{mg} / \mathrm{dl}$ respectively).

Oral administration of all the doses of the test drug extract through 5; 10 and 15 day's on blood glucose and body weight were given in Tables 3 and 4 . The blood glucose level of diabetic rats group significantly decreased from $355 \pm 10 \mathrm{mg} / \mathrm{dl}$ to $225 \pm 9 \mathrm{mg} / \mathrm{dl}$ on days 5 after treated with BGF extract. Oral administration of BGF $(25,50$ and $100 \mathrm{mg} / \mathrm{kg}$ body weight) through long duration decreased blood glucose as compared to diabetic rats. Continuous administration of BGF extract was found to significantly $(\mathrm{p}<0.05)$ decrease the blood glucose level to $140 \mathrm{mg} / \mathrm{dl}$. The body weight was lowered in diabetic rats as compared to normal rats. But when the animals were treated with BGF extract increased body weight as compared to diabetic rats. BGF extract ( $50 \mathrm{mg} / \mathrm{kg}$ body weight) increased body weight nearly as the normal compared to diabetic rat.

The data of the present work clearly demonstrated that, there was a significant increase in the mean value of sAST $(71 \pm 3 \mathrm{U} / \mathrm{ml})$ and sALT $(76 \pm 4 \mathrm{U} / \mathrm{ml})$ of the diabetic rats compared to that of the normal group (Tables 5 and 6). On the other hand, administration of BGF extract changes the sAST and sALT values to approximately control value.

For all parameters studies BGF at doses 25,50 and $100 \mathrm{mg} / \mathrm{kg}$ body weight showed significant effect. But BGF at $50 \mathrm{mg} / \mathrm{kg}$ body weight showed highest effect. The optimum dose of bitter gourd extract given to diabetic rat $50 \mathrm{mg} / \mathrm{kg}$ body weight.

\section{Discussion}

Alloxan has been observed to cause reduction of the beta cell of islets of Langerhans and induced hyperglycemia. The normal beta cells count was markedly reduce after alloxan treatment [24-29]. The data revealed that the subcutaneous injection of alloxan in a dose of $120 \mathrm{mg} /$ 
Citation: Othman OA (2016) Hypoglycaemic Activity of Bitter Gourd Fruits Extracts in Normal and Alloxan-Induced Diabetic Rats. J Microb Biochem Technol 8: 358-360. doi: 10.4172/1948-5948.1000308

\begin{tabular}{|c|c|c|c|c|c|}
\hline \multirow{2}{*}{ Groups } & \multirow{2}{*}{ Treatment } & \multicolumn{4}{|c|}{ Mean AST U/ml } \\
\cline { 3 - 6 } & & Initial & $\mathbf{5}$ days & $\mathbf{1 0}$ days & 15 days \\
\hline I & Normal & $32 \pm 2$ & $33 \pm 3$ & $33 \pm 2$ & $33 \pm 2$ \\
\hline II & Diabetic & $71 \pm 3$ & $70 \pm 3$ & $70 \pm 3$ & $72 \pm 2$ \\
\hline III & BGF 25 X & $66 \pm 3$ & $62 \pm 2$ & $58 \pm 3$ & $55 \pm 3$ \\
\hline IV & BGF 50X & $65 \pm 4$ & $52 \pm 3$ & $45^{*} \pm 3$ & $41^{*} \pm 2$ \\
\hline V & BGF 100X & $67 \pm 3$ & $58 \pm 4$ & $52 \pm 3$ & $47 \pm 2$ \\
\hline
\end{tabular}

Table 5: Effect of BGF extract in AST in diabetic rats.

\begin{tabular}{|c|c|c|c|c|c|}
\hline \multirow{2}{*}{ Groups } & \multirow{2}{*}{ Treatment } & \multicolumn{4}{|c|}{ Mean ALT U/ml } \\
\cline { 3 - 6 } & & Initial & $\mathbf{5}$ days & $\mathbf{1 0}$ days & 15 days \\
\hline I & Normal & $38 \pm 3$ & $39 \pm 3$ & $38 \pm 3$ & $39 \pm 3$ \\
\hline II & Diabetic & $76 \pm 4$ & $79 \pm 4$ & $82 \pm 4$ & $83 \pm 4$ \\
\hline III & BGF 25 X & $76 \pm 2$ & $71 \pm 3$ & $70 \pm 4$ & $62 \pm 3$ \\
\hline IV & BGF 50 X & $77 \pm 4$ & $62 \pm 4$ & $58^{*} \pm 3$ & $50^{*} \pm 2$ \\
\hline V & BGF 100 X & $77 \pm 3$ & $68 \pm 3$ & $60 \pm 3$ & $54 \pm 2$ \\
\hline
\end{tabular}

Result Mean \pm S.D

Significant $p<0.05$

$\mathrm{X} \mathrm{mg/kg}$ body weight

Table 6: Effect of BGF extract in ALT in diabetic rats.

$\mathrm{kg}$ body weight was a convenient dose for the induction of diabetes in rats. These results are in agreement with those reported data by Eskander and Won Jun [9] Sheweita et al. [25] who used $120 \mathrm{mg} / \mathrm{kg}$ body weight to produce diabetic rats.

The result of the present study indicates that BGF decrease blood glucose in alloxan diabetic rats. The possible mechanism include the stimulation of $\beta$-cells and release of insulin and activation of the insulin receptors. Alloxan has been shown to induce free radical production and cause tissue in jury [28]. The pancreas is especially susceptible to the action alloxan induced free radical damage. Other possible mechanism BGF extract can act as a free radical scavenger. Administration of BGF extracts reduction the activity of the liver enzyme. The decrease in the concentration of enzymes in alloxan treated rats given BGF may be as hepatoprotective agent and improvement of liver function. In the present study it was observed the body weight was decrease in alloxan diabetic rats [26] and administration of BGF extract increases body weight on alloxan diabetic. The possible mechanism the ability of BGF to protect body weight loss seems to be as a result of its ability to reduce hyperglycemia [30-32].

The isolation and structure determination of these compounds are currently in progress. The present study indicates that BGF possessed a significant hypoglycaemic effect and may be as hepatoprotective agent

\section{References}

1. al-Shamaony L, al-Khazraji SM, Twaij HA (1994) Hypoglycaemic effect of Artemisia herba alba. II. Effect of a valuable extract on some blood parameters in diabetic animals. J Ethnopharmacol 43: 167-171.

2. Al-Waili NS (1986) Treatment of diabetes mellitus by Artemisia herba-alba extract: Preliminary study. Clin Exp Pharmacol Physiol 13: 569-573.

3. Berger W (1985) Incidence of severe sideeffects during therapy with sulfonylureas and biguanides. Horm Metab Res Suppl 15: 111-115.

4. Bever O, Zahnd G (1979) Plants with oral hypoglycaemic action quart. J Crude Drug Res 17: 129-196.

5. Cerasi E, Luft R, Efendic S (1972) Decreased sensitivity of the pancreatic beta cells to glucose in prediabetic and diabetic subjects. A glucose dose-response study. Diabetes 21: 224-234.

6. Chakravarthy B, Sargj Gupta S, Gambhir S, Gode K (1980) Pancreatic betacell regeneration - A novel anti-diabetic mechanism of Pterocarpus marsupium, ROXB. Ind J Pharmac 12: 127.
7. Deckert T, Lauridsen UB, Madsen SN, Mogensen P (1972) Insulin response to glucose, tolbutamide, secretin and isoprenaline in maturity-onset diabetes mellitus. Dan Med Bull 19: 222-226.

8. Eisenberg DM, Kessler RC, Foster C, Norlock FE, Calkins DR, et al. (1993) Unconventional medicine in the United States. Prevalence, costs and patterns of use. N Engl J Med 328: 246-252.

9. Eskander EF, WonJun H (1995) Hypoglycemic and hyperinsulinemic effect of some Egyptian herbs used for the treatment of diabetes mellitus (type II) in rats. J Pharm Sci 36: 331-342.

10. Goldner M, Gomori G (1943) Alloxan induced diabetes. Endocrinology 3: $297-$ 299.

11. Gupta MP, Solis NG, Avella ME, Sanchez C (1984) Hypoglycemic activity of Neurolaena lobata (L.) R. BR. J Ethnopharmacol 10: 323-327.

12. Halliwell B, Gutteridge J (1985) Free radicals in biology and medicine.

13. Hikino H, Mizuno T (1989) Hypoglycemic actions of some heteroglycans of Ganoderma lucidum fruit bodies. Planta Med 55: 385.

14. Huupponen R (1987) Adverse cardiovascular effects of sulphonylurea drugs Clinical significance. Med Toxicol 2: 190-209.

15. Jahodár L (1993) [Plants with hypoglycemic effects]. Cesk Farm 42: 251-259.

16. Jimenez J, Risco S, Ruiz T, Zarzuelo A (1986) Hypoglycemic activity of Salvia lavandulifolia. Planta Med 260-262.

17. Lesabre B (1981) Diagnostique du Diabete; la nouvelle classification de L'OMS Concours Medical 1: 2267-2272.

18. Linquette M (1973) Precis d'endocrinologie. Masson et Cie 2: 1233-1245.

19. Mason RD (1976) In "Essential of Statistics Practice" Inc. Englewood Cliff, New Jersy.

20. Mossa J (1986) Experimental evaluation of some plants for their anti-diabetic activity. IRCS Med Sci 1: 13-14.

21. Petkov V, Manolov P (1978) Pharmacological studies on substances of plant origin with coronary dilatating and antiarrhythmic action. Comp Med East West 6: 123-130.

22. Atta-Ur-Rahman, Zaman K (1989) Medicinal plants with hypoglycemic activity J Ethnopharmacol 26: 1-55

23. REITMAN S, FRANKEL S (1957) A colorimetric method for the determination of serum glutamic oxalacetic and glutamic pyruvic transaminases. Am J Clin Pathol 28: 56-63.

24. Shanmugasundaram ER, Rajeswari G, Baskaran K, Rajesh Kumar BR, Radha Shanmugasundaram K, et al. (1990) Use of Gymnema sylvestre leaf extract in the control of blood glucose in insulin-dependent diabetes mellitus. $J$ Ethnopharmacol 30: 281-294.

25. Sheweita SA, Newairy AA, Mansour HA, Yousef MI (2002) Effect of some hypoglycemic herbs on the activity of phase I and II drug-metabolizing enzymes in alloxan-induced diabetic rats. Toxicology 174: 131-139.

26. Srikanta S, Gando O, Eisenbarth G, Stoeldner J (1983) Islet-cell antibodies and beta-cell function in monozygotic tripleta and twins initially discordant for type I diabetes mellitus. N Engl J Med 388: 322-325.

27. Tominaga M, Komiya I, Johnson JH, Inman L, Alam T, et al. (1986) Loss of insulin response to glucose but not arginine during the development of autoimmune diabetes in BB/W rats: relationships to islet volume and glucose transport rate. Proc Natl Acad Sci U S A 83: 9749-9753.

28. Torres IC, Suarez JC (1980) A preliminary study of hypoglycemic activity of Lythrum salicaria. J Nat Prod 43: 559-563.

29. Veiga F, Fernandes C, Teixeira $F(2000)$ Oral bioavailability and hypoglycaemic activity of tolbutamide/cyclodextrin inclusion complexes. Int J Pharm 202: 165171.

30. WHO/Acadia (1992) Rapport de Ja journee internationale du diabete.

31. Yaniv Z, Dafni A, Friedman J, Palevitch D (1987) Plants used for the treatment of diabetes in Israel. J Ethnopharmacol 19: 145-151.

32. Ziyyat A, Legssyer A, Mekhfi H, Dassouli A, Serhrouchni M, et al. (1997) Phytotherapy of hypertension and diabetes in oriental Morocco. J Ethnopharmacol 58: 45-54. 